\title{
Caracterização das assembléias de peixes da Bacia do Rio Corumbatai (SP)
}

\author{
Mauricio Cetra
}

\section{Resumo}

A bacia do rio Piracicaba tem recebido atenção especial das autoridades municipais, pois possui grandes problemas de aproveitamento de seus recursos hídricos. A bacia do rio Corumbataí, um dos principais afluentes da margem direita do rio Piracicaba, é regionalmente importante, não só porque ainda possui águas de boa qualidade, mas também por apresentar elementos raros na paisagem do interior do Estado. Esta tese teve o objetivo de caracterizar as assembléias de peixes na bacia do rio Corumbataí e fornecer ferramentas para avaliação de seu status ambiental. Foram escolhidos 4 rios principais com 3 pontos de coleta em cada um. Foram realizadas coletas no período de março a junho e setembro a dezembro de 2001, totalizando 24 coletas. Os dados bióticos foram avaliados através de medidas de diversidade. Para testar a hipótese de variação espaço-temporal da assembléia de peixes foi aplicado o modelo linear ANCOVA onde a variável resposta foi a riqueza de espécies; o fator foi ordem do rio; sendo utilizadas 2 covariáveis ambientais: temperatura e número de indivíduos, revelando uma variação espaço-temporal e padrões reconhecidos no meio acadêmico: relação espécie-área e Conceito de Rio Contínuo. Técnicas multivariadas foram aplicadas para determinar a correlação entre a riqueza e a paisagem no entorno do ponto de coleta, revelando que existem mais espécies em locais com maior cobertura vegetal e mata ciliar preservada. Algumas espécies de peixes se mostraram bons indicadores ambientais: Hypostomus strigaticeps, Hoplosternum littorale e Salminus hilarii; por outro lado o Astyanax altiparanae não se mostrou um bom indicador.

Palavras-chave: rio Corumbataí; assembléia de peixes; diversidade de espécies; bioindicadores
FICHA CATALOGRÁFICA PREPARADA PELA SEÇÃO DE TRATAMENTO

DA INFORMAÇÃO DO SERVIÇO DE

BIBLIOTECA - EESC/USP

Cetra, Mauricio

Caracterização das assembléias de peixes da Bacia do Rio Corumbatai (SP) / Mauricio Cetra. - São Carlos, 2003.

C423c

Tese (Doutorado) - Escola de Engenharia de São Carlos-Universidade de São Paulo, 2003.

Área: Ciências da Engenharia Ambiental.

Orientador: Prof. Dr. Miguel Petrere Júnior

1. Rio Corumbataí. 2. Assembléia de peixes. 3. Diversidade de espécies. 4. Bioindicadores. I. Título. 